\title{
Multiple interspecies recombination events within RNA2 of Grapevine fanleaf virus and Arabis mosaic virus
}

\author{
E. Vigne $\cdot$ A. Marmonier $\cdot$ M. Fuchs
}

Received: 24 March 2008/Accepted: 18 July 2008/Published online: 10 August 2008

(c) Springer-Verlag 2008

\begin{abstract}
Sequence alignments and SISCAN analyses inferred multiple interspecies recombination events within RNA2 of strains GHu of Grapevine fanleaf virus (GFLV) and Ta of Arabis mosaic virus (ArMV), two closely related subgroup A nepoviruses in the family Comoviridae. Interspecies recombination events were identified in the $5^{\prime}$ untranslated region, the putative homing protein and movement protein genes but not in the coat protein gene and $3^{\prime}$ untranslated region. These findings suggest a dynamic relationship between GFLV and ArMV, and a differential selection pressure on RNA2-encoded proteins with constraints in terms of function and co-adaptation that limit interspecies recombination to certain gene segments.
\end{abstract}

Grapevine fanleaf virus (GFLV) and Arabis mosaic virus (ArMV), two closely related members of the genus Nepovirus, family Comoviridae [16], are responsible for fanleaf degeneration, the most severe viral disease of grapevines $[1,5]$. These two viruses often occur in mixed infection in central European vineyards [5]. The bipartite genome of

The GenBank accession numbers of sequences reported in this paper are EF426852 and EF426853.

E. Vigne $\cdot$ A. Marmonier $\cdot$ M. Fuchs

Unité Mixte de Recherche Santé de la Vigne et Qualité du Vin, Institut National de la Recherche Agronomique and Université Louis Pasteur, 68021 Colmar, France

\section{Fuchs ( $₫)$}

Department of Plant Pathology and Plant-Microbe Biology, Cornell University, New York State Agricultural Experiment Station, Geneva, NY 14456, USA

e-mail: mf13@cornell.edu
GFLV and ArMV encodes replicase and protein maturation functions in RNA1, and a putative homing protein $\left(2 \mathrm{~A}^{\mathrm{HP}}\right)$, the movement protein $\left(2 \mathrm{~B}^{\mathrm{MP}}\right)$ and coat protein $\left(2 \mathrm{C}^{\mathrm{CP}}\right)$ in RNA2 (Fig. 1a). The same arrangement of protein domains within the RNA2-encoded polyprotein is conserved in picorna-like viruses [12]. The RNA2 of GFLV and ArMV have $60-66 \%$ nucleotide identity in the $5^{\prime}$ untranslated region (UTR), $68-78 \%$ in gene $2 \mathrm{~A}^{\mathrm{HP}}, 76-78 \%$ in gene $2 \mathrm{~B}^{\mathrm{MP}}, 67-68 \%$ in gene $2 \mathrm{C}^{\mathrm{CP}}$ and $72-73 \%$ in the $3^{\prime} \mathrm{UTR}$ [14, 21, 28, 29].

RNA recombination is a natural mechanism involved in genetic variation and evolution of plant virus populations $[7,15,30]$. It commonly occurs when the replicase complex switches template after encountering secondary RNA structures like hairpins and/or stretches of substantial similarity between donor and acceptor RNA strands during virus replication [18, 22, 23, 27, 31]. Intraspecies recombination has been documented for various GFLV strains with crossover sites distributed all along the open reading frame of RNA2 [19, 25, 26]. No information is available on interspecies recombination between GFLV and other viruses, in particular ArMV [16], albeit protein $2 \mathrm{~A}^{\mathrm{HP}}$ of ArMV strain NW has higher amino acid similarity with GFLV than with other ArMV strains [28]. In this study, we determined the sequence of RNA2 of GFLV strain GHu (GFLV-GHu) and ArMV strain Ta (ArMV-Ta), and identified interspecies recombination events in the $5^{\prime}$ UTR, genes $2 \mathrm{~A}^{\mathrm{HP}}$ and $2 \mathrm{~B}^{\mathrm{MP}}$ but not in gene $2 \mathrm{C}^{\mathrm{CP}}$ and the $3^{\prime}$ UTR. Our findings suggest a dynamic relationship between GFLV and ArMV, and a distinct evolutionary diversification of their RNA2-encoded proteins.

GFLV-GHu [9] and ArMV-Ta [13] were isolated from Vitis vinifera cvs. Gloriae Hungariae and Tannat, respectively. Their RNA2 was characterized from infected grapevine leaves by reverse transcription-polymerase chain 
Fig. 1 a Schematic representation of the GFLV and ArMV genome. The ORF of each genomic RNA is represented by an open rectangle, the flanking $5^{\prime}$ and $3^{\prime}$ UTRs by a black line, the VPg by a closed circle, and poly-A tails by $\mathrm{A}_{(\mathrm{n})}$. Processed proteins are indicated within each polyprotein $\left(1 \mathrm{~A}\right.$ : putative proteinase cofactor; $1 \mathrm{~B}^{\mathrm{Hel}}$. putative helicase; $1 \mathrm{C}^{\mathrm{VPg}}$ : $\mathrm{VPg}$; $1 \mathrm{D}^{\text {Pro }}$ : proteinase; $1 \mathrm{E}^{\mathrm{Pol}}$ : putative RNA-dependent RNA polymerase; $2 \mathrm{~A}^{\mathrm{HP}}$ : homing protein; $2 \mathrm{~B}^{\mathrm{MP}}$ : movement protein; and $2 \mathrm{C}^{\mathrm{CP}}$ : coat protein). Cleavage sites are indicated below polyproteins. b Phylogenetic relationship within RNA2 of GFLV-GHu (GHu: EF426852), ArMV-Ta (Ta: EF426853) and other GFLV (F13: NC_003623, NW: AY017338) and ArMV (but: AB279739, L: X81815, lil: AB279741, nar: AB279740, NW: NC_006056, U: X81814) strains for which full-length sequences are available in databases. NJ unrooted phylogenetic trees were reconstructed from RNA2 nucleotide sequences. Ellipses correspond to GFLV and ArMV groups. Numbers below critical branches are significant bootstrap values (\%). Scale bars represent a genetic distance of 0.1. $\mathbf{c}$ SISCAN analysis of aligned nucleotide sequences of RNA2 from recombinant GFLV-GHu with GFLV-F13 (filled circle) and ArMV-U (open circle). The window covered $200 \mathrm{bp}$ positions and moved through the alignment with a step size of $75 \mathrm{bp}$. Graph is based on $Z$ values using the total nucleotide identity scores. Recombination crossover sites are shown by a dotted line. d SISCAN analysis of aligned nucleotide sequences of RNA2 from recombinant ArMV-Ta with GFLV-F13 (filled square) and ArMV-U (open square). Parameters are identical to (A)

reaction (RT-PCR) using total RNA extracted with the RNeasy Plant Mini Kit (Qiagen) and degenerate primers selected in conserved regions $[14,19,21,25,26,28]$ (Table 1). The $5^{\prime}$ and $3^{\prime}$ RNA2 extremities of GFLV-GHu and ArMV-Ta RNA2 were determined with the rapid amplification of cDNA ends (RACE) technology (Roche). All GFLV-GHu and ArMV-Ta cDNAs were cloned in plasmid pGEM-T (Promega), transformed into Escherichia coli JM109 cells, and sequenced by the dideoxynucleotide chain termination method with primers hybridizing to viral RNA2 regions (Table 1) as well as primers SP6 and T7. The RNA2 sequence of GFLV-GHu, ArMV-Ta and other GFLV and ArMV strains was compared using CLUSTAL W [24]. Phylogenetic relationships determined with neighbour-joining [20] inferred two distinct groups, as expected (Fig. 1b). Interestingly, GFLV-GHu and ArMVTa had an intermediate position between the GFLV and ArMV groups (Fig. 1b).

SISCAN analysis [8] of the 3,806 bp long RNA2 indicated that GFLV-GHu is an interspecies recombinant between GFLV and ArMV with multiple crossover sites mapping to the $5^{\prime}$ UTR between nucleotides (nts) 137 and 160 , the 36 part of gene $2 \mathrm{~A}^{\mathrm{HP}}$ between nts 880 and 921 , and the $3^{\prime}$ part of gene $2 \mathrm{~B}^{\mathrm{MP}}$ between nts 1,969 and 2,031 (Fig. 1c). The chimeric nature of GFLV-GHu RNA2 was further supported by the size of its $5^{\prime}$ UTR (264 bp) which is similar to most ArMV strains [14, 28], including ArMVTa (260 bp), but larger than other GFLV strains (231$232 \mathrm{bp)}[21,26,28]$. To the best of our knowledge, this is the first report of recombination in the $5^{\prime}$ UTR of a nepovirus genomic RNA. Recombination was suspected

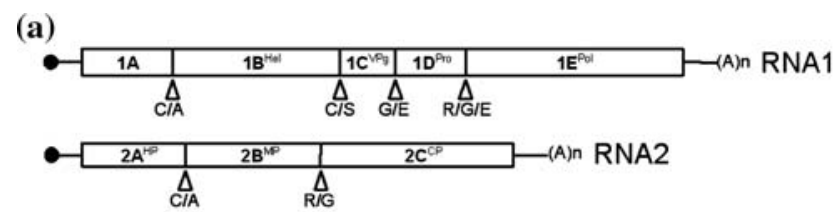

(b)

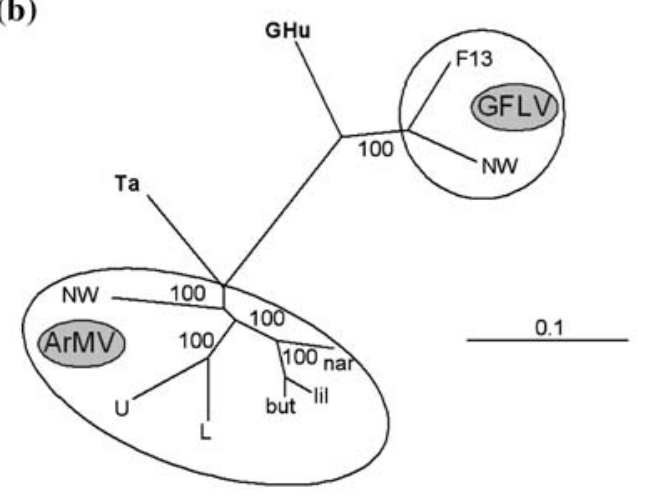

(c)

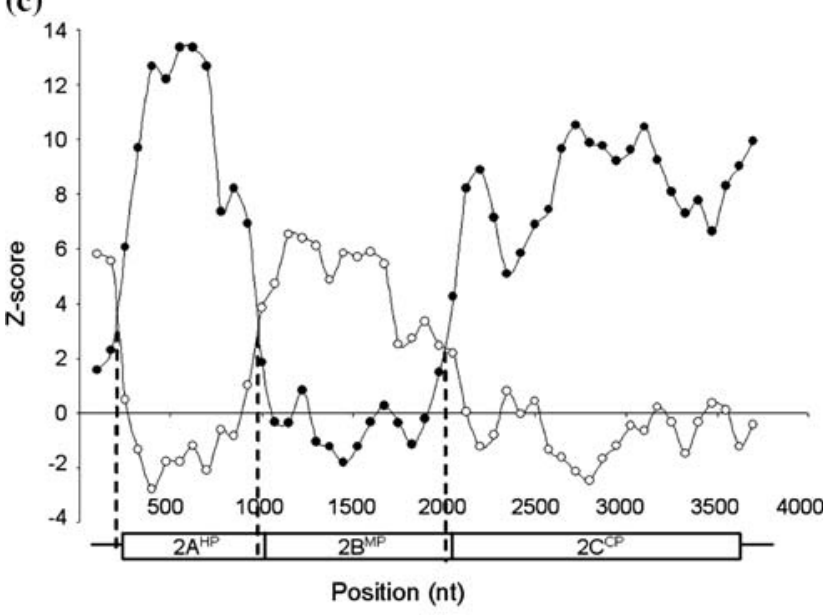

(d)

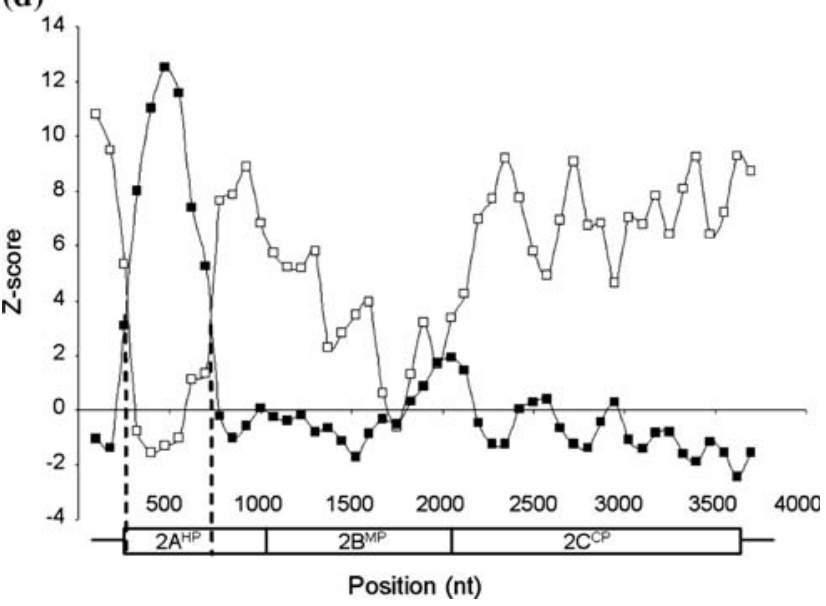

previously in this region but empirical evidence was lacking [16]. An overall high AU content (63-72\%), a predicted stem loop structure (GAGTTAAGAAACTC) conserved between GFLV and ArMV in positions 145-159 
Table 1 Oligonucleotides used in this study

\begin{tabular}{|c|c|c|c|c|}
\hline Primer & Purpose & GFLV position ${ }^{\mathrm{a}}$ & ArMV position ${ }^{\mathrm{b}}$ & Sequence $5^{\prime}-3^{\prime c}$ \\
\hline 395 & RT-PCR & $298-320(+)$ & $294-316(+)$ & GCCTGYTGGGCTGCTGGDAAGAA \\
\hline 396 & RT-PCR & 2419-2444 (-) & $2412-2437(-)$ & TTRAACCACATDGCRTGDCCRCACAA \\
\hline 397 & RT-PCR & $3736-3755(-)$ & $3708-3727(-)$ & GGCAAGTGTGTCCAAAGGAC \\
\hline 398 & RT-PCR & $1957-1975(+)$ & 1956-1974 (+) & TGGGARARYRTNGAGGAAC \\
\hline 225 & $5^{\prime}$ RACE and sequencing & $705-722(-)$ & $692-709(-)$ & AGTGCCGCAGCTCTCGAC \\
\hline 446 & $5^{\prime} \mathrm{RACE}$ & $807-827(-)$ & NA & TCATACCACTTCCTCCAAGTG \\
\hline 447 & $5^{\prime} \mathrm{RACE}$ & NA & $797-817(-)$ & TCATACCATCTCCTCCAGGTG \\
\hline 490 & $3^{\prime} \mathrm{RACE}$ & $2632-2649(+)$ & NA & TGCCCTCCCATATTCTTT \\
\hline 77 & $3^{\prime} \mathrm{RACE}$ & NA & $2058-2074(+)$ & ATGAGCACTACTACGCG \\
\hline 449 & Sequencing & $374-392(-)$ & $370-388(-)$ & ACAGTTTGGCGGAAGGAGG \\
\hline 443 & Sequencing & NA & $940-958(-)$ & GCCCTAGCACAAGACTGCC \\
\hline 400 & Sequencing & NA & $1235-1254(+)$ & TGCATATCTTGGTGCTGCTG \\
\hline 429 & Sequencing & NA & $1548-1566(-)$ & CCATATTGCGCTCGTGCCC \\
\hline 445 & Sequencing & NA & $2269-2290(-)$ & GCGTCAAAACTCATAACCCACG \\
\hline 110 & Sequencing & NA & $2191-2217(+)$ & AGTGGATTACTGCAGGACTTGTTATGC \\
\hline 140 & Sequencing & NA & $2795-2812(+)$ & TAGCCCTTGCACTTATGG \\
\hline 438 & Sequencing & NA & $3369-3388(+)$ & GGCATGGATGGAGCATCCCG \\
\hline 8 & Sequencing & 886-904 (-) & NA & GAGGATTTTGGATTGGGGG \\
\hline 32 & Sequencing & $1221-1238(-)$ & NA & GCATTCCTGGCCTGCTCA \\
\hline 28 & Sequencing & $1302-1323(+)$ & NA & TTACGCCCCTAGGGGTTTGTGG \\
\hline 13 & Sequencing & $1609-1627(-)$ & NA & AAATGGCTCTAGCTAACCC \\
\hline 115 & Sequencing & $2012-2032(+)$ & NA & CTGTGAGGATTGATAGAAACG \\
\hline 78 & Sequencing & $2109-2129(-)$ & NA & GCCTGGCAATCCTTGGGAATG \\
\hline 16 & Sequencing & $2269-2289(+)$ & NA & GGATTGACATGGGTGATGAGC \\
\hline 423 & Sequencing & $2421-2439(-)$ & NA & CCACATDGCRTGACCACACA \\
\hline 432 & Sequencing & $2629-2650(+)$ & NA & ACTTGCCСТCCCATATTCTTTG \\
\hline 424 & Sequencing & 3082-3101 (-) & NA & AAAGAGAGATCTGGGCGCAC \\
\hline 431 & Sequencing & $3178-3200(+)$ & NA & GGCTCTCGTTTCTTTGATTTYAC \\
\hline 122 & Sequencing & $3328-3348(+)$ & NA & AGCGGGAGCGTTACCATCACG \\
\hline 29 & Sequencing & $3491-3512(-)$ & NA & TGATCCAATTTAATTGCCATCC \\
\hline
\end{tabular}

${ }^{a}$ GFLV positions are given for strain GHu (EF426852). Hybridization on minus (-) and plus (+) RNA strand is indicated; NA not applicable

b ArMV positions are given for strain Ta (EF426853)

${ }^{\mathrm{c}} \mathrm{D}$ : A or $\mathrm{G}$ or T; R: A or G; Y: C or T; $\mathrm{N}$ : A or $\mathrm{C}$ or $\mathrm{G}$ or $\mathrm{T}$

of GFLV-GHu RNA2 and an AU-rich region (76\%) sequence downstream of the recombination site could account for template switching of the replicase complex during negative strand synthesis of viral RNA2. Similar contexts have been shown to facilitate polymerase pausing at AU-rich folded sequences and association between acceptor and donor RNA strands in other viruses [18, 22, 27, 31].

Gene $2 \mathrm{~A}^{\mathrm{HP}}$ of GFLV-GHu is more related to GFLV than ArMV (86-90\% vs. 57-64\% nt identity), except the ultimate 117 nts at the $3^{\prime}$ end which are closer to ArMV than GFLV (81-86\% vs. $68-72 \%$ nt identity), suggesting a recombination event between nts 880 and 921 (Fig. 1c). Amino acid alignments confirmed a mosaic structure at the C-terminus of protein $2 \mathrm{~A}^{\mathrm{HP}}$, notably with a characteristic
ArMV motif LQ/RAAL in positions 220-224 (Fig. 2c). For gene $2 \mathrm{~A}^{\mathrm{HP}}$ of ArMV-Ta, the $5^{\prime}$ end is more closely related to GFLV than ArMV (82-87\% vs. $44-58 \%$ nt identity) whereas the core region and $3^{\prime}$ end are closer to ArMV than GFLV (85-88\% vs. $72-77 \%$ nt identity). SISCAN analysis of the 3,780 bp long RNA2 of ArMV-Ta predicted interspecies recombination crossover sites between nts 255 and 269 and between 570 and 599 nts (Fig. 1d). The chimeric structure of protein $2 \mathrm{~A}^{\mathrm{HP}}$ of ArMV-Ta was confirmed with characteristic GFLV motifs WAAGKNP in positions 14-20, SFRQTVKEDVQ in positions 38-48, RMFSWK in positions 58-63, and WHFVLTGER in positions $77-85$ at the N-terminus (Fig. 2a) as well as a conserved ArMV motif LQ/RAAL in position 221-225 at the C-terminus (Fig. 2c). Similar 
Fig. 2 Alignment of the a $\mathrm{N}$-terminus, b core region, and c C-terminus of protein $2 \mathrm{~A}^{\mathrm{HP}}$ of several representative GFLV (GHu, F13, NW, A17d: AY780901, Vol55c3: DQ922673) and ArMV (Ta, L, nar, NW, U, PV46: AY090003) strains for which sequences are available in databases. White zones indicate nonsimilar or weakly similar amino acids, clear grey zones indicate conservative amino acids, and dark grey zones indicate identical amino acids. Residues conserved in a GFLV at the $\mathrm{N}$-terminus and in $\mathbf{c}$ ArMV at the C-terminus are underlined. The location of the putative recombination sites in protein $2 \mathrm{~A}^{\mathrm{HP}}$ of GFLV-GHu and ArMV-Ta are boxed
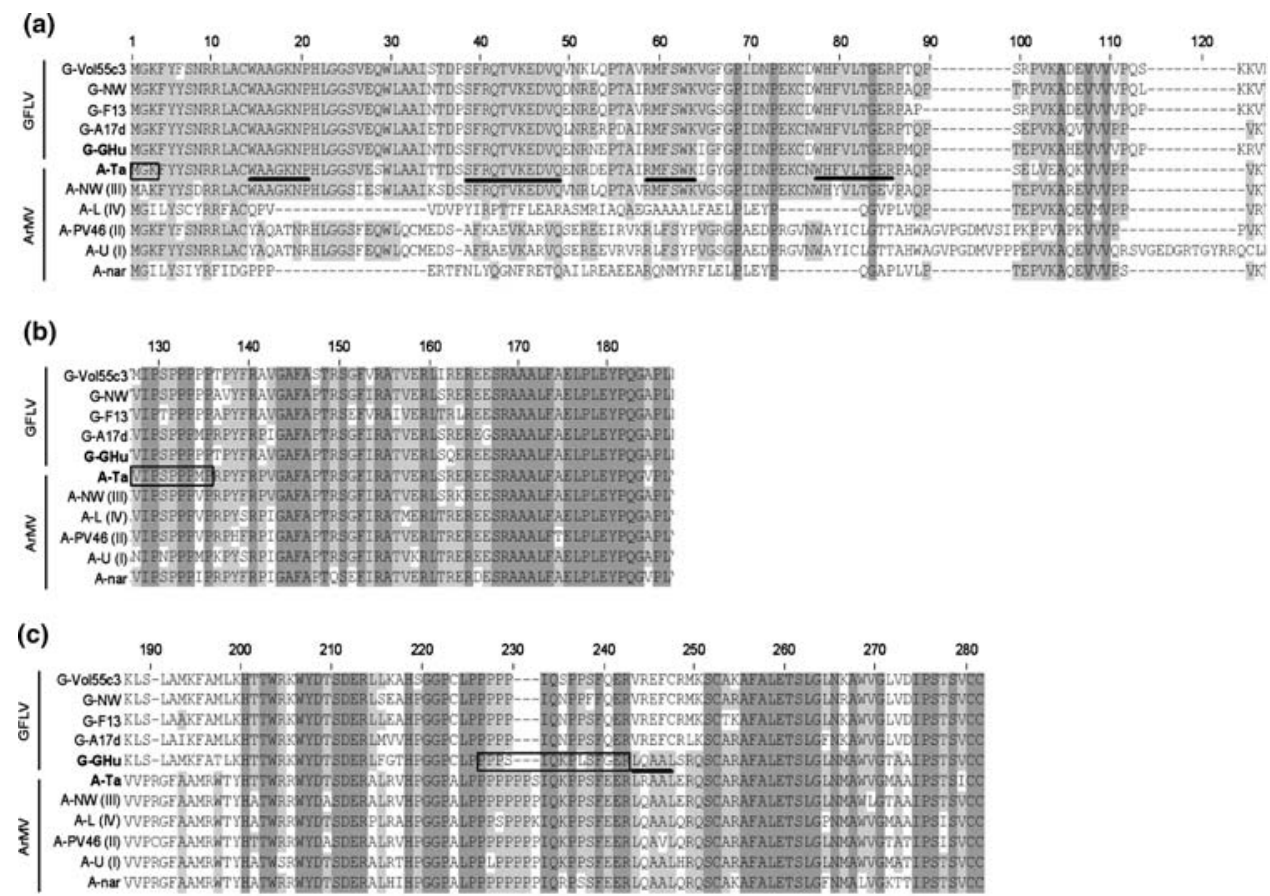

results were reported previously for gene $2 \mathrm{~A}^{\mathrm{HP}}$ of other ArMV strains although no reference to recombination was made [28, 29]. A distinct degree of relatedness between different parts of a protein is an indicator of extensive recombination events in its past evolution, as shown for Picornaviridae [23]. Gene $2 \mathrm{~A}^{\mathrm{HP}}$ of GFLV and ArMV is the only RNA2 encoded-gene showing variability in size and high amino acid diversity [19, 26, 29], suggesting an evolutionary divergence relative to genes $2 \mathrm{~B}^{\mathrm{MP}}$ and $2 \mathrm{C}^{\mathrm{CP}}$.

Further evidence of interspecies recombination in GFLV-GHu was found in gene $2 \mathrm{~B}^{\mathrm{MP}}$. This gene is more closely related to ArMV than GFLV (81-83\% vs. $78-79 \%$ nt sequence identity). Accordingly, protein $2 \mathrm{~B}^{\mathrm{MP}}$ is of ArMV origin, except the final 17 C-terminal residues, which are of GFLV origin and conserved among GFLV strains $[19,21,26,28]$. Within this stretch, the final nine amino acids (EPRLSSTVR) are strictly conserved and critical for a functional interaction between chimeric GFLV/ArMV proteins $2 \mathrm{~B}^{\mathrm{MP}}$ and GFLV protein $2 \mathrm{C}^{\mathrm{CP}}$ to achieve systemic plant infection [3]. These data inferred that the natural recombination patterns of GFLV-GHu in gene $2 \mathrm{~B}^{\mathrm{MP}}$ mirror almost perfectly the functionality of synthetic chimeric GFLV/ArMV RNA2 constructs. Similar results were reported for a plant DNA virus [15]. Recombination in gene $2 \mathrm{~B}^{\mathrm{MP}}$ was previously documented between Grapevine chrome mosaic virus (GCMV) and Tomato black ring virus (TBRV) [11], two nepoviruses of subgroup B [16]. The high nucleotide sequence homology in gene $2 \mathrm{~B}^{\mathrm{MP}}$ of nepoviruses [17] may have favored homologous recombination and the emergence of not only functional chimeric proteins but also functional hybrid viruses between GFLV and ArMV from nepovirus subgroup A, and GCMV and TBRV from nepovirus subgroup $\mathrm{B}[16]$.

Interspecies recombination was not detected in gene $2 \mathrm{C}^{\mathrm{CP}}$ of GFLV-GHu and ArMV-Ta. It is possible that genetic exchange within the capsid gene is less likely to generate viable viral offsprings than elsewhere in RNA2. Synthetic GFLV/ArMV recombinants produced in our laboratory confirm this prediction because the exchange of partial gene $2 \mathrm{C}^{\mathrm{CP}}$ segments results mainly in nonfunctional chimeric RNA2 whereas exchange of full-length gene $2 \mathrm{C}^{\mathrm{CP}}$ results in infectious chimeric RNA2 if the biological compatibility between proteins $2 \mathrm{~B}^{\mathrm{MP}}$ and $2 \mathrm{C}^{\mathrm{CP}}$ is maintained [2-4]. Important selection pressure notably due to structural constraints imposed on protein $2 \mathrm{C}^{\mathrm{CP}}$ for subunit assembly into particles and vector transmission could account for a limited evolution of gene $2 \mathrm{C}^{\mathrm{CP}}$. A similar differential selection pressure on structural and nonstructural proteins is reported for Picornaviridae [30].

No recombination was detected in the $3^{\prime}$ UTR of GFLV$\mathrm{GHu}$ and ArMV-Ta in spite of recombination-promoting signals $[18,22,27,31]$, including a high AU content (67\%), a predicted hairpin loop (AAAAAGAKTTTBH(Y/-) $\mathrm{T}(\mathrm{W} /$-)TCTTTTT) in positions 3,767-3,788 of GFLV-GHu and 3,739-3,761 of ArMV-Ta RNA2, and a lower nucleotide sequence identity at the $5^{\prime}$ end than at the $3^{\prime}$ end with other GFLV and ArMV strains (28-42\% vs. 85-91\%). A transfer of the $3^{\prime}$ UTR between GCMV and TBRV was reported in pseudorecombinant isolates consisting of GCMV RNA1 and TBRV RNA2 [10]. 
The closely related GFLV and ArMV have a great potential for creating hybrid RNA molecules because they can co-exist in grapevines [5] over extended time, i.e. 3040 years, their RNA2 have moderate to high sequence identity (60-78\%), and their replication mechanism is errorprone due to a lack of proofreading mechanism associated with their RNA-dependent RNA polymerase [7, 30].

Our observations with GFLV-GHu and ArMV-Ta are consistent with a differential selection pressure exerted on structural and nonstructural genes with constraints in terms of gene function and co-adaptation within RNA2 that limit interspecies recombination to certain gene segments, as shown for other viruses $[6,15,23]$. Although rare, interspecies recombination can impact the evolution of virus populations and lead to the emergence of new viruses and eventually new diseases $[7,30]$. It will be interesting to determine the biological properties and fitness characteristics of GFLV-GHu and ArMV-Ta, and examine if their reduced virulence $[9,13]$ is associated with any of the interspecies recombination events identified in this study.

Acknowledgments This work was partially supported by a competitive grant from the European Commission (Environmental impact assessment of the transgenic grapevines and plums on the diversity and dynamics of virus populations, QLK3-CT-2002-02140). We are indebted to Dr. L. M. Yepes for critically reading the manuscript.

\section{References}

1. Andret-Link P, Laporte C, Valat L, Laval L, Ritzenthaler C, Demangeat G, Vigne E, Pfeiffer P, Stussi-Garaud C, Fuchs M (2004) Grapevine fanleaf virus: still a major threat to the grapevine industry. J Plant Pathol 86:183-195

2. Andret-Link P, Schmitt-Keichinger C, Demangeat G, Komar V, Fuchs M (2004) The specific transmission of Grapevine fanleaf virus by its nematode vector Xiphinema index is solely determined by the viral coat protein. Virology 320:12-22

3. Belin C, Schmitt C, Gaire F, Walter B, Demangeat G, Pinck L (1999) The nine C-terminal residues of the Grapevine fanleaf nepovirus movement protein are critical for systemic virus spread. J Gen Virol 80:1347-1356

4. Belin C, Schmitt C, Demangeat G, Komar V, Pinck L, Fuchs M (2001) Involvement of RNA2-encoded proteins in the specific transmission of Grapevine fanleaf virus by its nematode vector Xiphinema index. Virology 291:161-171

5. Bovey R, Gärtel W, Hewitt WP, Martelli GP, Vuittenez A (1980) The most important virus diseases of grapevine. In: Bovey $R$, Gärtel W, Hewitt WP, Martelli GP, Vuittenez A (eds) Virus and virus-like diseases of grapevines. Editions Payot, Lausanne, pp 46-56

6. Escriu F, Fraile A, Garcia-Arenal F (2007) Constraints to genetic exchange support gene coadaptation in a tripartite RNA virus. PLoS Pathogens 3:e8

7. Garcia-Arenal F, Fraile A, Malpica JM (2001) Variability and genetic structure of plant virus populations. Annu Rev Phytopathol 39:157-186

8. Gibbs MJ, Armstrong JS, Gibbs AJ (2000) Sister-scanning: a monte carlo procedure for assessing signals in recombinant sequences. Bioinformatics 16:573-582
9. Huss B, Walter B, Fuchs M (1989) Cross-protection between Arabis mosaic virus and Grapevine fanleaf virus in Chenopodium quinoa. Ann appl Biol 114:45-60

10. Le Gall O, Candresse T, Dunez J (1995) Transfer of the $3^{\prime}$ nontranslated region of grapevine chrome mosaic virus RNA-1 by recombination to tomato black ring virus RNA-2 in pseudorecombinant isolates. J Gen Virol 76:1285-1289

11. Le Gall O, Lanneau M, Candresse T, Dunez J (1995) The nucleotide sequence of the RNA-2 of an isolate of the English serotype of tomato black ring virus: RNA recombination in the history of nepoviruses. J Gen Virol 76:1279-1283

12. Le Gall O, Sanfaçon H, Ikegami M, Iwanami T, Jones T, Karasev A, Lehto K, Wellink J, Wetzel T, Yoshikawa N (2007) Cheravirus and Sadwavirus: two unassigned genera of plant positivesense single-stranded RNA viruses formerly considered atypical members of the genus Nepovirus (family Comoviridae). Arch Virol 159:1767-1774

13. Legin R, Bass P, Etienne L, Fuchs M (1993) Selection of mild virus strains of fanleaf degeneration by comparative field performance of infected grapevines. Vitis 32:103-110

14. Loudes AM, Ritzenthaler C, Pinck M, Serghini MA, Pinck L (1995) The $119 \mathrm{kDa}$ and $124 \mathrm{kDa}$ polyproteins of Arabis mosaic nepovirus (isolate $\mathrm{S}$ ) are encoded by two distinct RNA2 species. J Gen Virol 76:899-906

15. Martin DP, van der Walt E, Posada D, Rybicki EP (2005) The evolutionary value of recombination is constrained by genome modularity. PLoS Genetics 4:e51

16. Mayo MA, Robinson DJ (1996) Nepoviruses: molecular biology and replication. In: Harrison BD, Murant AF (eds) The plant viruses, polyhedral virions and bipartite RNA. Plenum, New York, pp 139-185

17. Mushegian AR (1994) The putative movement domain encoded by nepovirus RNA2 is conserved in all sequenced nepoviruses. Arch Virol 135:437-441

18. Ohshima K, Tomitaka Y, Wood JT, Minematsu Y, Kajiyama H, Tomimura K, Gibbs AJ (2007) Patterns of recombination in turnip mosaic virus genomic sequences indicate hotspots of recombination. J Gen Virol 88:298-315

19. Pompe-Novak M, Gutiérrez-Aguirre I, Vojvoda J, Blas M, Tomazic I, Vigne E, Fuchs M, Ravnikar M, Petrovic N (2007) Genetic variability within the RNA2 of Grapevine fanleaf virus. Eur J Plant Pathol 117:307-312

20. Saitou N, Nei M (1987) The neighbour-joining method: a new method for reconstructing phylogenetic trees. Mol Biol Evol 4:406-425

21. Serghini M, Fuchs M, Pinck M, Reinbolt J, Walter B, Pinck L (1990) RNA2 of Grapevine fanleaf virus: sequence analysis and coat protein cistron location. J. Gen Virol 71:1433-1441

22. Shapka N, Nagy PD (2004) The AU-rich RNA recombination hot spot sequence of Brome mosaic virus is functional in Tombusviruses: implications for the mechanism of RNA recombination. J Virol 78:2288-2300

23. Simmonds $P$ (2006) Recombination and selection in the evolution of picornaviruses and other mammalian positive-stranded RNA viruses. J Virol 80:11124-11140

24. Thompson JD, Higgins DJ, Gibson TJ (1994) CLUSTAL W: improving the sensitivity of progressive multiple sequence alignment through sequence weighting, position-specific gap penalties and weight matrix choice. Nucleic Acids Res 22:4673-4680

25. Vigne E, Bergdoll M, Guyader S, Fuchs M (2004) Population structure and genetic variability within isolates of Grapevine fanleaf virus from a naturally infected vineyard in France: evidence for mixed infection and recombination. J Gen Virol 85:2435-2445

26. Vigne E, Demangeat G, Komar V, Fuchs M (2005) Characterization of a naturally occurring Grapevine fanleaf virus recombinant isolate. Arch Virol 150:2241-2255 
27. Vives MC, Rubio L, Sambade A, Mirkov TE, Moreno P, Guerri J (2005) Evidence of multiple recombination events between two RNA sequence variants within a Citrus tristeza virus isolate. Virology 331:232-237

28. Wetzel T, Meunier L, Jaeger U, Reustle GM, Krczal G (2001) Complete nucleotide sequences of the RNAs 2 of German isolates of Grapevine fanleaf and Arabis mosaic nepoviruses. Virus Res 75:139-145
29. Wetzel T, Fuchs M, Bobko M, Krczal G (2002) Size and sequence variability of the Arabis mosaic virus protein 2A. Arch Virol 147:1643-1653

30. Worobey M, Holmes EC (1999) Evolutionary aspects of recombination in RNA viruses. J Gen Virol 80:2535-2543

31. Zhang C, Gu H, Ghabrial SA (2007) Molecular characterization of naturally occurring RNA1 recombinants of the comovirus Bean pod mottle virus. Phytopathol 97:1255-1262 